play than in the past, and he emphasized the need for a spirit of inquiry and the development of researchmindedness as a national characteristic.

In the second paper at this session, Dr. J. W. Jenkin dealt with Midland industries and their research needs. These industries are exceedingly varied and multifarious ; but there are some common factors, and whether the work be mechanical or scientific, real progress can only come from a ruthlessly objective study of all relevant facts and creative thinking to find relations between them and to devise the crucial experiments. There appears to be a need for a closer link between the scientific work characterizing the newer industries and the engineering inventiveness common in the older. This can often be supplied by making the same persons responsible both for the research results and their translation into practice. The bridging of the gap between the discovery and its commercial exploitation, the development stage, should not be left as a spare-time activity of those primarily responsible for administration, production or sales. Men are needed with wide sympathies to direct research away from over-emphasis on a restricted field of technology into closer liaison with development.

Sir Edward Appleton presided over the second session of the Conference, which dealt with industrial research in the Midlands. He commented on the increasing readiness of many scientific workers in universities and technical colleges to place their knowledge at the disposal of industry, but at the same time thought that the encouragement of cooperative action through the research associations is the most effective means of supplying the particular scientific knowledge which industry requires. $\mathrm{Mr}$. F. G. W. King, technical director of the Dunlop Rubber Co., Ltd., contributed a well-documented paper on Midland research organisations, activities and facilities, in which he suggested that since most of the industrial research in this large and varied region is carried out in the laboratories of the large firms, although related contacts spread all over the country, investigation of methods of increasing productivity, particularly the skilled study of flow production, and close co-operation between research units and their related groups in firms, research associations and universities ar $\epsilon$ required, in addition to further research. Such co-operation should be facilitated by fuller documentation of the broad fields of the research, to give a general idea of the problems studied, and he suggested that the research secretariat of the Federation of British Industries might help in the organisation of such documentation. Research, moreover, would only be fully effective if its results were known and appreciated by other experts and skilled workers in the industry. Appendixes to Mr. King's paper include an analysis of industries in the Birmingham region, and lists of industrial research in progress in technical colleges and universities, either in the region or outside the region, when specially related to its industries. The information relating to the universities was taken mainly from the "Notes on Current Scientiflc Researches in the United Kingdom" prepared for the Royal Society Empire Scientific Conference last year.

The concluding paper of the Conference, by Mr. J. C. Pearce, dealt with the smaller Midland firm and its application of research. Mr. Pearce suggested that the firm not large enough to provide one fulltime or part-time technical man to act in liaison with outside developments should treat its research association as a source of information and apply for information as and when required. It should give the staff of the Association opportunities of assessing the nature of its work and problems so that replies can be suited to its ability to give effect to them. The research associations should treat this information from individual firms as strictly confidential, but use it to build up that part of the current research programme dealing with experimental work directed towards the solution of specific problems common to the industry as a whole or to sections of it. $\mathrm{Mr}$. Pearce believes that the major functions of a research association, namely, the application of new knowledge through development and the dissemination of knowledge by intelligence activities, has been least satisfactorily solved.

In the discussion Mr. L. E. Lines, repudiating the suggestion that young industrial scientific workers should be excused military service, said that Great Britain is suffering from seeking too much security'. Dr. Quarrel pointed out that this year we shall have only one fifth of the number of scientific recruits which was available to industry in 1938, and only one half of the average number for the war years. Sir William Akers, in summing up, said that some of the observations indicated that in certain directions planning by the Government has been very incom. plete, and asked whether we should not now put all the technically and industrially fit people into the economic war.

\section{OIL PLANTS IN EAST AFRICA}

$\mathrm{T}$ HE plan for mechanized production of groundnuts in East Africa described in the recent White Paper (Cmd. 7030) and the inherent importance of all oleaginous crops to-day give added interest to an informative and well-documented review of oil plants in East Africa by A. Glendon Hill, director of the East African Agricultural Research Institute (E. Afr. Agric. $J ., 12,140$; 1947). It deals with ground-nuts, sesame and sunflower.

Ground-nuts. One of the most valuable of oil plants, with an oil content of nearly 50 per cent in the shelled nuts, it is widely grown by natives in East Africa, mainly for their own food; though it has not hitherto attracted the European farmer to any extent. In addition to oil, the nuts are rich in protein (about 30 per cerit), so that after extraction of the oil the press cake forms a valuable cattle food. Mr. Glendon Hill thinks this cake may in future be largely used for manufacture of artificial wool such as 'Ardil'. The main ground-nut areas of East Africa are the western, central, lake and southern provinces of Tanganyika, the eastern province of Uganda, and the Nyanza and coast provinces of Kenya. Only a small proportion of the crop is exported-21,000 tons in 1942. In 1936, 290,000 acres in Tanganyika and 167,000 acres in Uganda were under ground-nuts; and in 1944 it was estimated there were 400,000 native growers in Tanganyika.

Types and varieties, soils and manures, cultivation, harvesting, diseases and pests, and crop economics are described. There are a great number of varieties, which can be grouped into three main types, of which the 'bunch' or 'upright' is the most desirable, as exemplified by Virginia Bunch, which is early, drought-resistant, gives good yield and oil content, 
but has hard shell. Spanish Bunch is even earlier, but with smaller yield. The ground-nut responds markedly to plant selection, which has been done in East Africa for some years with occasional notable success ; for example, in evolving wilt-resistant strains. As it is not a self-fertile plant, selection and isolation of new strains is comparatively easy. Selection has been mostly directed to high yield and kernel percentage, with resistance to rosette disease ; but not, so far as is known, to evenness in ripening-lack of which often causes serious trouble in harvesting - or to long dormancy and high oil content. In Uganda, bunch types are encouraged, but selection is proceeding with creeping types owing to their resistance to locusts. Selection has resulted in higher yielding varieties in some areas; but owing to the varying behaviour of different selections depending on season, final choice is difficult. In Nigeria, selection over five years resulted in 25 per cent yield increase in bunch type and 16 per cent in creeping type. Work with existing East African types is thought to be better than with imported varieties.

The best soils are light, sandy, well-drained loams, not too rich in organic matter; addition of lime and phosphate is often beneficial. The ground-nut fits in well with several different rotations, including cotton and maize. Fairly close spacing to keep the ground well covered is important, and weeds are often allowed to grow for this purpose. Yields per acre vary enormously according to conditions : from 200 to $2,200 \mathrm{lb}$. unshelled on native farms, though the average is nearer $600 \mathrm{lb}$., which is slightly less than the yield obtained in the United States. Mechanized farming in Queensland gives 3,600 lb. unshelled.

Sesame (simsim, ufuta, gingelly, bene, or til) has also high oil content, usually about 50 per cent, but sometimes much higher, with about 20 per cent protein and 18 per cent carbohydrate. Calcium content in the undecorticated product is remarkably high (1 per cent, mostly in the seed-coat), while phosphorus is $0 \cdot 7$ per cent. The main sesame areas in East Africa are : southern province of Tanganyika, northern province of Uganda, and Nyanza province of Kenya. It is mostly grown by native farmers for their own use, and the average yield is 350-400 lb. per acre. Care has to be taken not to contaminate with wild sesame (S. radiatum or Ufuta mwitu), which contains a substance toxic to cattle. There are many varieties, but the principal types are white and black. In Uganda, selection has aimed at high. yielding white-seed types for export, and has resulted in some improvement; as also in Tanganyika. Soils and climate, cultivation, harvesting, storage, pests, etc., are described. From the economic point of view, the yield from sesame is only about one third that of ground-nuts, and it is a major crop only where soils are sticky and make ground-nut harvesting expen. sive. It does not interest European farmers greatly.

Sunflower. As is well known, this crop covers vast areas in the U.S.S.R., and to a less degree in the Argentine, the Balkans, and China. It is not grown to any large extent in Africa. The best known in the past have been the giant types with heads 12-22 in. across, but easily sensitive obviously to wind and rain. A dwarf type has been introduced in Britain and elsewhere, such as the Pole Star, Southern Cross, Jupiter, and Mars. Attempts are being made to obtain seed of these varieties for trial in East Africa; but whether it is economically feasible there depends on world prices. Some notes on cultivation, etc., are given.

\section{CHANK MARKING EXPERIMENTS AT TUTICORIN}

GOR the purpose of ascertaining the migrations and growth-rate of the chank, marking experiments were begun in 1931 by the Madras Fisheries Department*. Since then about 5,000 chanks have been marked and liberated on the chank beds of Tuticorin. It was thought that there might be a migration of chanks from those beds to the Ceylon beds on the other side of the Gulf of Mannar. The experiments have shown that such migrations do not take place; but there are movements of chanks from one bed to another in the immediate vicinity. The greatest distance covered by any marked chank was nine miles.

There is marked variation in observed rates of growth, some specimens showing very little increase over long periods, while others have grown as much as $23 \mathrm{~mm}$. in length in 23 months. The reason for this disparity is not known, but the suggestion is made that it may be due to variations in hydrological and other conditions on the different beds. This is a fairly safe guess, but it is no more than that. Much more work will have to be done and the data handled much more carefully and expertly before a sound knowledge of the bionomics of the chank can be acquired. It should not be necessary to state, for example, that of the 5,000 odd chanks that have been marked "only about 259 were recovered". Chanks are by no means minute animals, and the exact number recovered by the investigator must surely be known and should be recorded and reported upon with equal accuracy. In the absence of such accuracy little reliance can be placed upon any results obtained or conclusions reached.

Moreover, no scientific investigator should send out a paper in which only the local (common) name of the organism under investigation is given. Presumably the chank referred to in this paper is the gastropod Turbinella pyrum, Linn., but nowhere is this stated.

* Preliminary Study of the Chank Marking Experiments at Tuticorin. By K. Chidambaram and M. Mukandan Unny. A paper read before the Zoological Section of the Indian Science Congress, January 1947.

\section{FORTHCOMING EVENTS}

\author{
Monday; May 12
}

FARMers' CuUB (at the Royal Empire Society, Craven Street, Strand, London, W.C.2), at 2.30 p.m.-Mr. Martin Jones: "Ley Farming and the Livestock Population".

INSTITUTION OF POST OFFICE FLECTRICAL ENGINEERS (at the Institution of Electrical Engineers, Savoy Place, Victoria EmbankInstitution of Electrical Engineers, Savoy Place, Victoria Embankment, London, W.C.2), at 5 p.m.-Mr. W;

Soclety of PUBlic ANalysts aND other ANaLytical Chemists, BIOLOGICAL METHODS GROUP (in the West Hall, Royal Society of Medicine, 1 Wimpole Street, London, W.1), at 6 p.m.-Symposium on "The Production and Care of Laboratory Animals", Part 3. Dr. J. I. M. Jones and Dr. Eric C. Wood : "Housing"; General Discussion on all subjects.

Tuesday, May 13

ELECTRICAd Association FOR WOMEN (at the Connaught Rooms, Great Queen Street, London, W.C.2), at 10.30 a.m.-Fourteenth Annual General Meeting.

ZoOI.GICAL SOCIETY OF LONDON (at Regent's Park, London, N.W.8.), at 5 p.m. - Scientific Meeting.

INSTITUtion of EleCtRICAL ENGINEERS, RAdio SECTION (at Savoy Place, Victoria Embankment, London, W.C.2), at 5.30 p.m.-Discussion on "Future Trend of Component Design for the Services" (to be opened by Dr. G. W. Sutton and Mr. E. M. Lee).

IUIUMINATING ENGINEERING SOCIRTY (at the Institution of Mechanical Engineers, Storey's Gate, St. James's Park, London, S.W.1), at 6 p.m. "Annual General Meeting; at 6.30 p.m.-Dr. N. A. Ha 